Valentyna Smachylo, Candidate of Economic Sciences, Associate Professor, Professor of the Department of Economics, Kharkiv National University of Civil Engineering and Architecture (Kharkiv, Ukraine);

Veronika Khalina,

Candidate of Economic Sciences, Associate Professor of the Department of Economics, Kharkiv National University of Civil Engineering and Architecture (Kharkiv, Ukraine);

Yevheniia Kylnytska,

Candidate of Economic Sciences, Associate Professor of the Department of Economics, Kharkiv National University of Civil Engineering and Architecture (Kharkiv, Ukraine)

\title{
DEVELOPMENT OF THE SOCIAL ENTREPRENEURSHIP IN UKRAINE AS AN INNOVATIVE FORM OF THE BUSINESS
}

In this article the theoretical study of the main aspects of social entrepreneurship is described, namely: there generalized views of scientists on its features, delineated the term "social enterprise", "socially responsible company", "charities", studied the experience of social entrepreneurship in Europe and the specifics of its legislative regulation, the basic model of the social entrepreneurship in accordance with international practice in this particular type of business, organizational and legal forms and scope. The basic problem of the formation of social entrepreneurship in Ukraine has been revealed and developed a roadmap for its further development.

Keywords: social entrepreneurship, innovative forms of business, signs of social entrepreneurship, models of social entrepreneurship, roadmap.

DOI: $10.21272 / \mathrm{mmi} .2018 .1-17$

Formulation of the problem generally. European integration vector of development of Ukraine is impossible without the implementation of modern management principles, common for the European Union, among which the socialization of economic processes is particularly noted.

Doing business on the higher evolutionary level is manifested in the formation of the new cluster of entrepreneurs' activity is aimed at innovative sustainable development that is involved the social and environmental problems of society, not just its own enrichment.

Accordingly, it conducts to the transformation of relations in the triad "state - society - business" and raises a number of problems caused by the formation of the qualitatively new relationship: the changing role of the state, principles of doing business, the demands of society to the two previous institutions.

It is therefore necessary to study the theoretical and methodological foundations of social entrepreneurship and European practices for the purpose of spreading and adapting it to the Ukrainian context.

Analysis of recent researches and publications and selection of outstanding issues. At the present stage of development, issues of social entrepreneurship are dedicated labor of many leading international experts, and local researchers. Note that the basic theoretical research in this area include foreign scientists such as G. Diso [2, 3, 4], A. Peredo and M. McLean [2, 5], F. Sprekli [8], M. Nyssens [9], J. Martin [10, 11], whose publications are the basis for the study; local researchers, Sotula's O.V. [24], Berezyaka I. [19], Sirenko N.M. and Lunkin T.I. [18], Naumova M. [2], Cote L. [11]. Furthermore, it should be noted broad practical experience in social entrepreneurship in Europe presented by the activities B. Drayton [14], M. Yunus [28], K. \& H. Schwab [29], J. Skoll [30]. As social entrepreneurship for Ukraine is rather new phenomenon, the domestic achievements in this area are based mainly on the study of advanced experience of foreign scientists, are both theoretical and practical, making research more thorough, deep and adapted to the specific conditions of business of Ukraine. 
Negligible level of development issues of implementation and maintenance of social entrepreneurship as an innovative model of development of Ukraine requires both domestic scholar's theoretical research achievements and study of existing practices in this area to further dissemination in the activities of national agents of the economy. Current researches in the field social entrepreneurship are non-systematic and in need of synthesis and regulation for building an effective ecosystem in which operate social enterprises. In addition, we believe that the state's role in the process of dissemination of advanced models driving of the economic activity is enormous, and it needs the development of mechanisms to facilitate public.

Based on the foregoing, the purpose of the article is to build a road map for development of social entrepreneurship based on entities research, identification of signs, and analysis of patterns and directions of social entrepreneurship development.

Basic materials with substantiation of the result of the research. Globalization of economic processes and its socially-oriented development became the driving force of the transformation of socioeconomic systems, that resulted in the emergence of innovative forms of implementation of business initiatives - social entrepreneurship, is the aim of which is meeting social needs along with doing business.

This innovative form of economic management is emerged in the late twentieth century as the response to social antagonisms that are not fully resolved by the state, although the origins of its occurrence relating to earlier periods. The cradle of social entrepreneurship is considered to be the UK, where in the nineteenth century there have emerged cooperatives, which combined the values of the community and businesses. Obviously, the absence of theoretical and / or methodological developments in this area did not prevent its manifestations in human history that had allowed evolving to the international recognition of the institution as higher than a legitimate business or corporate philanthropy of the corporate. So far more specifically in 1978 at the College of Beachwood in Yorkshire, in the UK, there was established and defined the concept and structure of social enterprise [8], which was based on the cooperative of entrepreneurship and joint ownership and responsibility not only for income, but for social wealth and ecology (Triple Bottom Line). Now it makes sense to talk about the transformation triad "state - society - business" and the emergence of so-called "fourth" sector - social entrepreneurship that causes the number of terminological and methodological disagreements and absence of a comprehensive vision of the implementation of new business models in the local realities due to lack of organizational, economic and legal framework. Despite the relatively long development of social entrepreneurship as the practical activities, theoretical and methodological research in this area is very limited in Ukraine, based on advances in scientific and legal field in Europe and America. Let us refer to the fundamental issues that must include this category for understanding its essential loads and provide definitions. The most famous approaches to defining characteristics of social entrepreneurship are grouped in Fig. 1.

Critical analysis of the data presented in Fig. 1 suggests the ambiguity and controversy socioeconomic category of "social entrepreneurship" at the same time; it should be noted common features that distinguish most authors:

- entrepreneurship is aimed at solving social problems involving representatives of social groups to participate in it with funds received from this activity (the principle of self-sufficiency and financial independence);

- innovative way to solve social problems, which insists the founder of Ashoka - B. Drayton [14];

- the possibility of spreading to other regions and countries, economies of scale.

From the represented signs of social entrepreneurship, authors are it most impressed by the approach presented in [11], where, besides the social orientation of (social aspect), economic feasibility (economic dimension) and innovative solutions (innovative aspects) the possibility of spreading to other 
territories, areas, etc is taken into account. Thus, social entrepreneurs - enterprising individuals who direct business not on their own enrichment, but to address pressing social needs and the creation of social welfare.

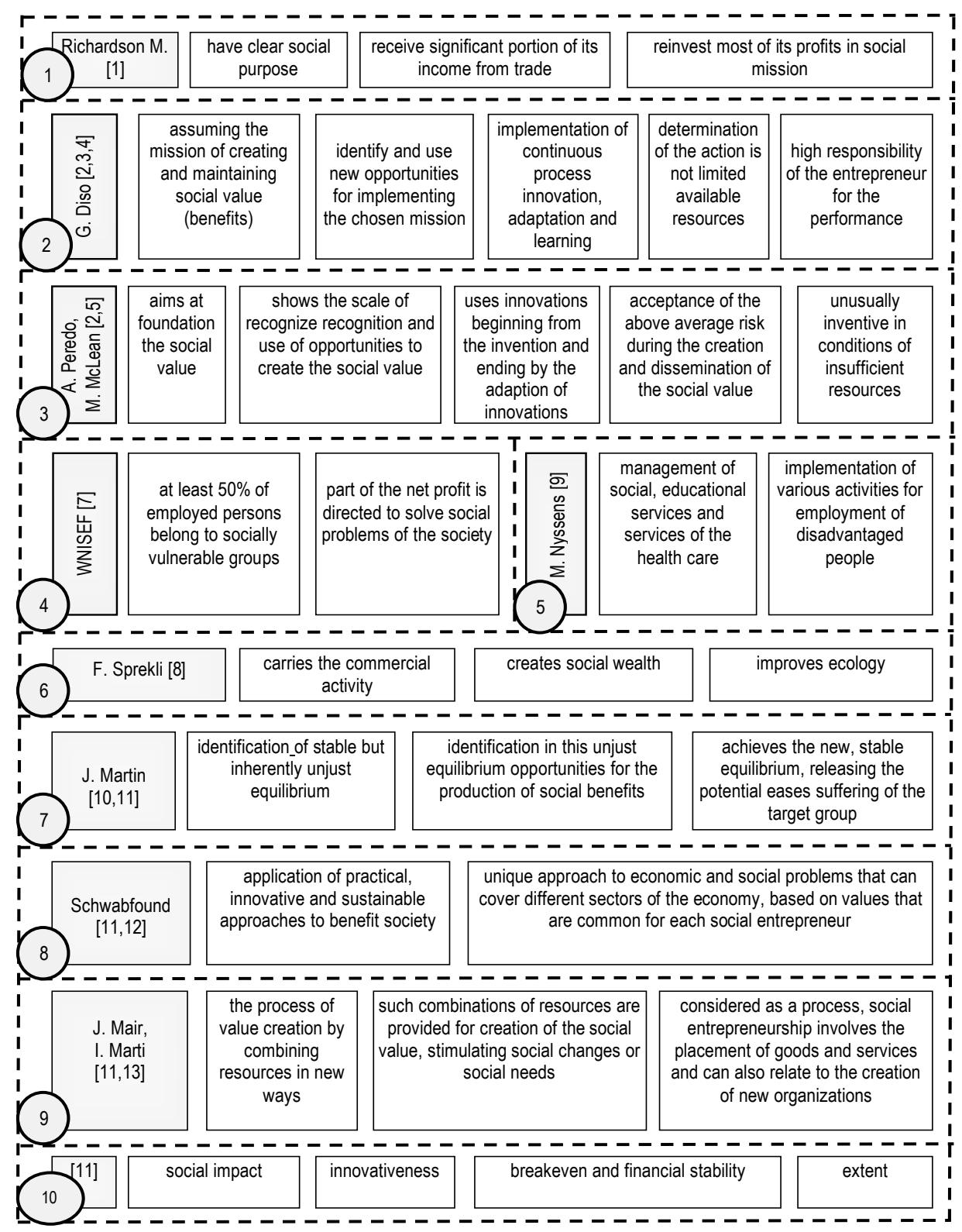

Figure 1 - Synthesis signs subjects of social entrepreneurship by various authors (developed by the authors based on [1-13]) 
Interpretation of characteristics of social entrepreneurship you may see in Fig. 1 indicates the presence of the difference between common business, charitable organizations, socially responsible businesses and, directly, thesocial entrepreneurship, combining the social mission of creation and business mechanisms for its provision. Accordingly, it requires the distinction of these concepts.

According to the Commercial Code of Ukraine, enterprise is an independent, proactive, systematic, at own risk economic activity carried out by business entities (entrepreneurs) to achieve economic and social benefits and profit [15].

Although this definition also implies the existence of social results of economic activities, the actual local business practices are far from receiving positive social outcomes and focused mainly on enriching owners and complete disregard for the problems of society, community, labor groups, environmental issues, etc.

Socially responsible enterprises which operate on the principles of the UN Global Compact [16], sustainable development 2016-2030 years [17] are concerned by the problems of stakeholders and take steps to resolve them according to their needs, opportunities, interests, without neglecting their own economic interests.

Thus, their activities in the social sphere are determined by their own perspective, interests, popularity, desire to improve the image and obtain intangible competitive advantage. Charities and organizations (the so-called NGOs) are not commercial in nature and focused on philanthropic activities receiving funding from various businesses, donations from people, other donors and using them to reduce social tension in society and solve certain problems or weaknesses of society.

In contrast to the socially responsible business, social entrepreneurship primarily aimed at solving social problems of particular group, community, region, state, and only then - for economic benefits from the entity or operating on the basis of breakeven. It is believed that the specified type of enterprise is partly taking over the role of the state and is therefore an essential element in government development mechanisms.

In Europe, where the level of social entrepreneurship has a higher degree than in Ukraine it is already accumulated some experience in state support of this scope, defining its priority. Social entrepreneurship is growing rapidly in European countries, solving the problem of unemployment, social protection and social inclusion. Accordingly, provisions on organizational and economic aspects of the regulation provided in the law in Italy (Law on social cooperatives 1991), Poland (Law on Social Cooperatives, 2006), Great Britain (The Public Services (Social Value) Act (Act public services (social values), 2012), Greece (Law 4019 / 09-30-2011 "On social economy and social enterprises"), UK (2004) [18]. The most popular legal form of doing social business in European countries is cooperative, "cooperatives social solidarity" (Portugal), "cooperative social initiatives" (Spain), "company's social purpose" (Belgium), "social cooperatives of collective ownership" (France) [19].

In addition to these countries, social entrepreneurship is widespread in other European countries: Germany, Slovakia, Hungary, Norway, Czech Republic, Slovenia, Lithuania as well as in the US, Canada, Japan, South Korea and Brazil.

Of course, there is no the only one correct model of doing social business. Each country individually, on the national level solves this issue by using different regulatory mechanisms and support in this area. In this regard, there are four models of social entrepreneurship [19]:

- North European model of Belgium, Netherlands, Sweden, Norway is characterized by the active support of the state (Government plan to support entrepreneurship "Good idea - provided the Future" (2015), Research Council of Ministers of the Nordic countries in relation to potential cooperation in the development of social entrepreneurship (2013));

- Models of USA, Canada, and Japan are based on the use of charity (philanthropic model) and are characterized by control at the enterprise level, which is more of socially responsible business; 
- Central European Model of Austria, Germany, and France is characterized by targeted support to social programs and business projects; government support and "hybrid" financing;

- British model distinguished by high level of social investment and high diversification of financing options.

As we can see, the development of social entrepreneurship is widely represented both in European countries and American and Asian ones. But according to [19], Ukraine, where the activity is only at the initial stage of its development, is closer to European way of development, which is to support by the government and various donors. As well this choice is stipulated by European integration vector of development of our country as the result of signing the Association Agreement with the EU. At the same time, we believe that in our country there are much more social problems than in these countries. The presence, depth and diversification of social problems of our time which are gaining characteristics of systemic social crisis, are not driving factor in the formation and development of social entrepreneurship. It requires the certain legal framework, organizational and economic mechanisms of doing business in this area.

Unfortunately, the government of our country did not note this trend as the priority, as it was done by the Government of Norway (in October 2015 government plans to support entrepreneurship "Good idea - a secure future" are adopted, the separate section which is to support the development of social entrepreneurship [20]). Neither strategy for sustainable development "Ukraine - 2020" [21], nor National strategy for regional development until 2020 [22], just as regional development strategy (cities) that are built based on its, are declared the development of social entrepreneurship. Although in 2011 there was an attempt to legalize social business by submitting the bill which was rejected by the Committee on Tax Policy VRU [23]. The above demonstrates the need for initiating development of project documents in this area at the state-regional level. At this stage the purposes of "Millennium sustainable development Ukraine 2016-2030" have no final version and have not been formally approved, it is therefore appropriate in the form operating objectives or direction of the business to prescribe measures for the development of social entrepreneurship in Ukraine that will find its echo at all levels of the hierarchy of socio-economic system and will speed up its popularization.

As for the organizational and legal forms of social entrepreneurship, cooperatives have been marked as its priority form, moreover in the UK there are "companies operating in the interests of the community" - social interest companies [19].

The absence of regulatory framework of activity of subjects of social entrepreneurship allows us to speak about official lack it's in Ukraine, but in fact this activity has been prevailing in recent years, especially with the beginning of the armed conflict in the East of our country.

However, in the various regulatory and legal sources there are provisions that allow the creation of companies that can be classified as social. [24] Therefore they distinguish such basic forms of social entrepreneurship in Ukraine [24]:

- non-profit organization (NPO) engaged in business in their core activities;

- NPO opens its own business, the part of its income finances its programs;

- enterprise for people with disabilities: the company is exempt from income tax if more than $50 \%$ of its employees are people with disabilities.

Research on the prevalence of social entrepreneurship in our country has revealed that the creation directory of social enterprises Ukraine on the site http://www.socialbusiness.in.ua is initiated, that provides information support to all who wish to engage in social business in Ukraine. In this resource directory 2013 there are about 10 subjects, while researchers speak about 55 units [25] and in catalog this year there are more than 80 units. Unfortunately, not all directories are published because the work is ongoing on the formation and filling. These differences are explained by the lack of unified criteria for inclusion in the subject's social entrepreneurship and that distorts the information field and demonstrates 
the system problems on the formation of social entrepreneurship in Ukraine.

Authors' monitoring of territorial location of local social enterprises, which is based on criteria of WNISEF [7], that is these are entities that conduct business, but are not charitable foundations or organizations existing on grants, showed that out of the 32 studied social companies almost the same number are in Kyiv (8 units) and Lviv (7 units), 2 enterprises are in Kharkiv, Zhmerentsi and Zhytomyr, although, of course, this list can be extended (Fig. 2).

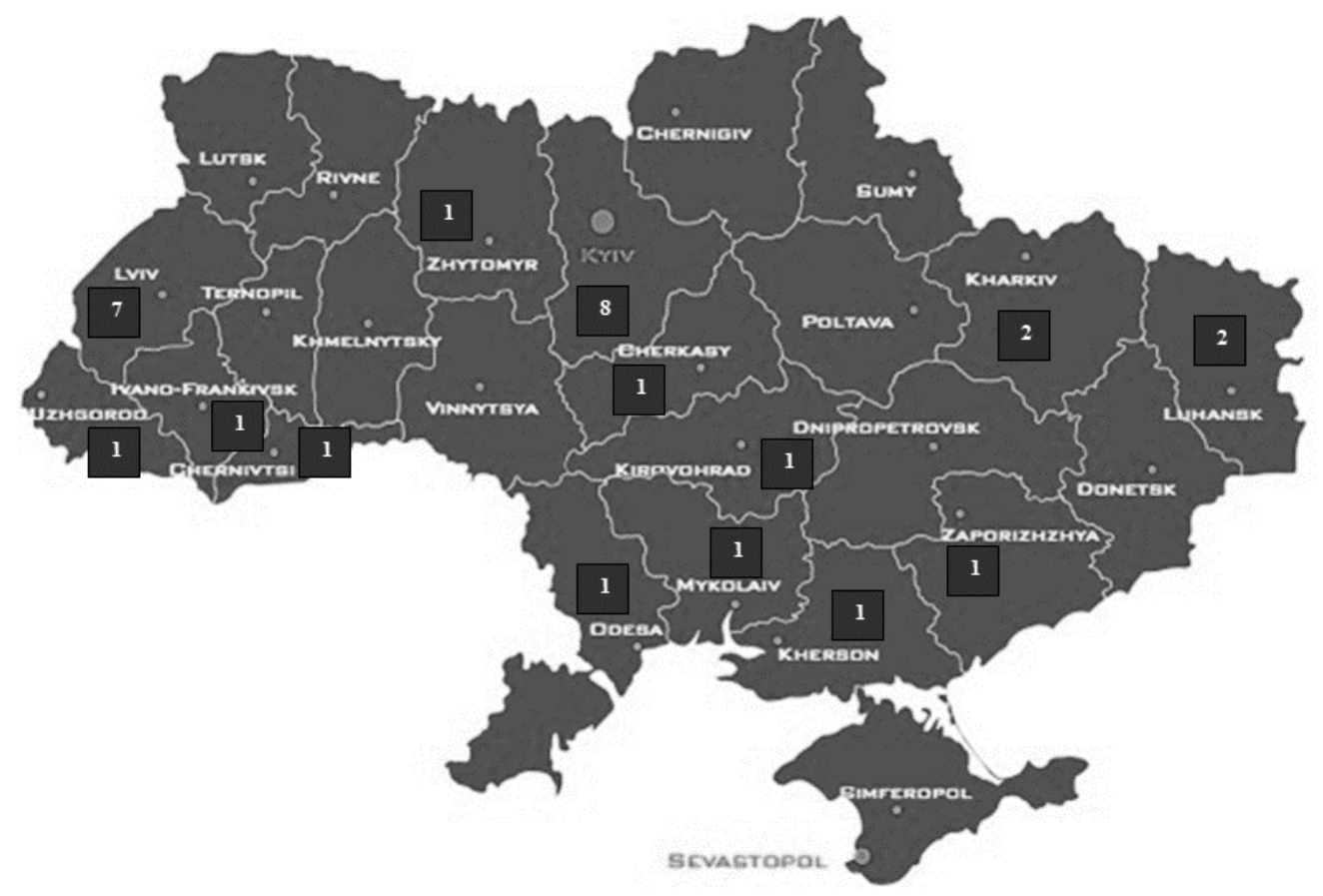

Figure 2 - Location of subjects of social entrepreneurship through Ukraine, the figures respond to the number of social enterprises (developed by the authors based on $[2,11,14,18-19,25]$ )

Furthermore, it should be noted there are other web resources that are initiated by social entrepreneurs to support the latest industry: "Community social entrepreneurs" http://socbiz.net; "Sustainable Business Club" http://sbiz.club; "East Europe Foundation" http://www.eef.org.ua; "Ukrainian Philanthropists Forum" http://ufb.org.ua; WNISEF http://www.wnisef.org and others.

In addition to the problems of legal regulation of conduct social business in Ukraine, it should be noted a number of barriers to its development (Fig. 3).

Based on the analysis of the theoretical heritage and of domestic practices of social business there has been formed the problematic field development, which is presented by the following areas:

- in the Ukrainian legislation there is no legal prerequisites for maintaining social entrepreneurship, which does not clearly define the subject of social entrepreneurship;

- theoretical developments in this area are mostly represented by the works of foreign scientists;

- lack of interest of the state and local authorities in the development of social entrepreneurship leads to absence of reasonable mechanisms for maintenance and revitalization in the area, as well as 
appropriate infrastructure reflecting passive role of the state in the formation for the institution in Ukraine;

- low level of awareness of various sectors of society of social entrepreneurship and its role in social and economic processes;

- weak diversification of financial sources, making it difficult to launch the social business, and limited funding from the budgets of all levels;

- weak human potential due to lack of high school education training programs in the field of social entrepreneurship.

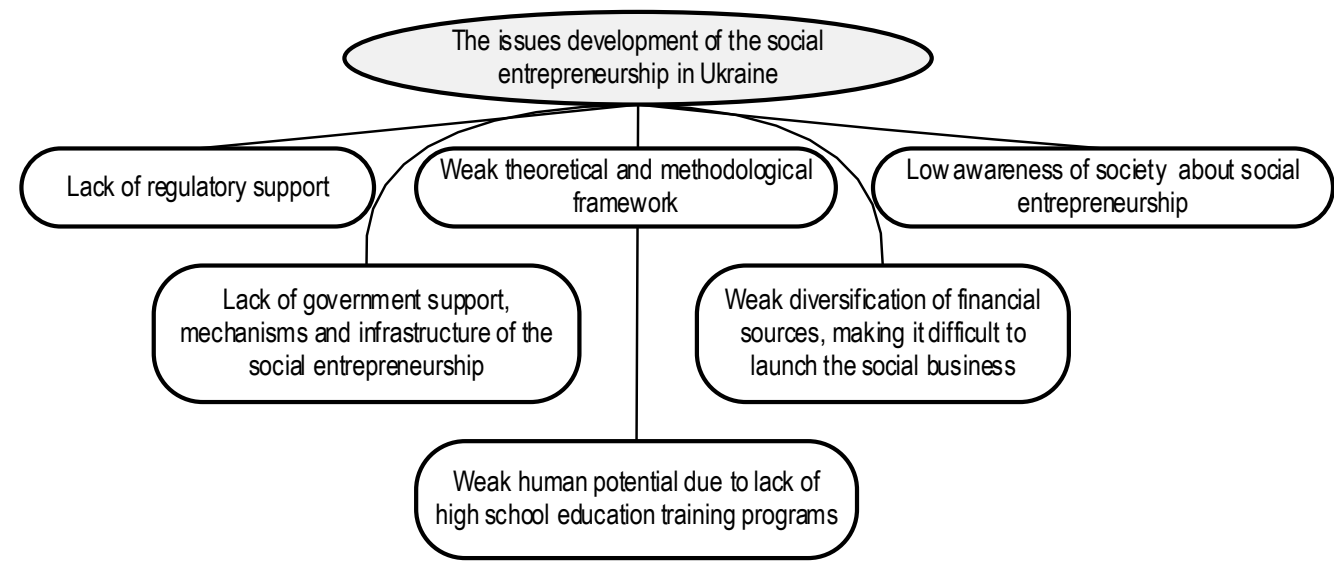

Figure 3 - The issue development of the social entrepreneurship in Ukraine (developed by the authors based on [12, 13])

Defined by the authors perspective requires the comprehensive approach to solving by combining in the single mechanism for the state, local authorities, businesses, charitable organizations, foundations, and community.

Modern transformations of socio-economic systems require the use of new methodological approaches for management decisions. One of such methods, which is new to the post-Soviet countries, is the method of mapping the road (road map). This method is very popular in the West (countries) appeared in the last quarter of the twentieth century and performs as both the predictive and planning functions. In general, road maps are aimed at information support of decision-making for the development of object mapping.

Its effectiveness is due to the use of the Deming cycle or abbreviated form of the scientific method PDCA (Plan - Do - Check - Act, "Plan - Do - Checks, Corrects / Action"). Schematically the essence of the method is shown on Fig. 4.

Road mapping connects the expectations of ideas, strategy and plan development of the process and builds over time the main steps of the process on a "past - present - future". It can be represented as a single-step scenario of development of control object that graphically is represented by the graph of the management process, which reflects the strategically significant events that determine the development of facility management, and the sequence of their occurrence.

The object management, in this case, is an institution of social entrepreneurship. As a result of research by the authors grounded topicality of social entrepreneurship and detected problem concerning its development in Ukraine. 


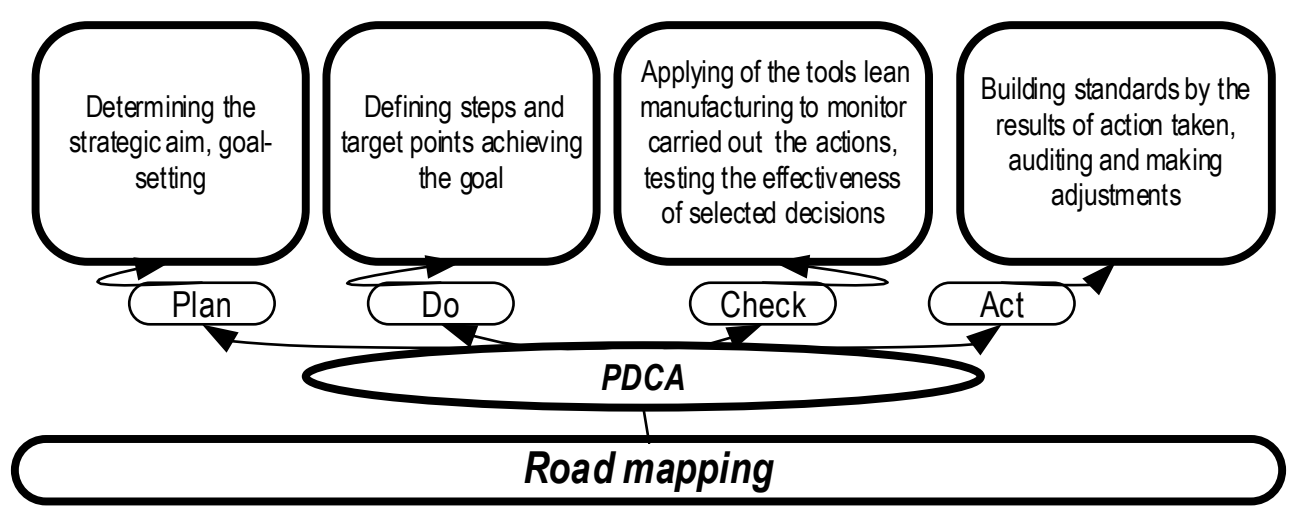

Figure 4 - Schematic display of process road mapping (developed by the authors based on $[26,27]$ )

On the basis of developments in this area [26, 27], the authors have developed the generalized road map development of the social entrepreneurship, which is shown in Fig. 5.

From Fig. 5 it is clear that the priority areas of development of the social entrepreneurship are designed for a four-year period (2017-2020). The mentioned areas corresponding to four key problematic issues to be resolved over a specified period, namely:

1. Providing support for subjects of social entrepreneurship that are starting out.

2. Development of legal regulatory framework for social entrepreneurship.

3. Increase of availability and diversification of financial resources for social entrepreneurship.

4. Organizational and economic aspects of creation of effectively ecosystem functioning.

The road mapping is of generalized nature and can be specified for each area. It is recommended for the general public: the state, local governments, international institutions, subjects of social entrepreneurship, local and charitable foundations. By deadline it coincides with the main strategic documents of Ukraine [21, 22].

Conclusions and directions of feather researches. As the result of the conducted research we can assert that:

- social entrepreneurship presents the unique, innovative, hybrid form of business, which is designed primarily to solve acute social problems, that is to perform partial functions of the state, with the achievement of social and economic effects and effects scalability;

- countries of Europe, America and Asia have significant theoretical and methodological achievements and practical experience in social entrepreneurship, where the state plays the significant role as the institution that determines the priority vectors of development, forms of organizational, economic and legal basis;

- development of social entrepreneurship is important for Ukraine at the current stage, since in the country there has accumulated large number of social issues that are required urgent solutions and linking both internal as external impacts;

_ despite the significant problem field that has been defined by the authors, social entrepreneurship in Ukraine does exist and it has the tendency to spread;

- the road mapping development of the social entrepreneurship in our country, proposed by the authors' team, will ensure the smooth interaction of all participants in the formation of an effective 
ecosystem in which the subjects of social entrepreneurship operate, there is the constructive dialogue between the government and businesses, with the support of European partners, and it will as soon as possible make social entrepreneurship legally approved innovative forms of business in Ukraine.
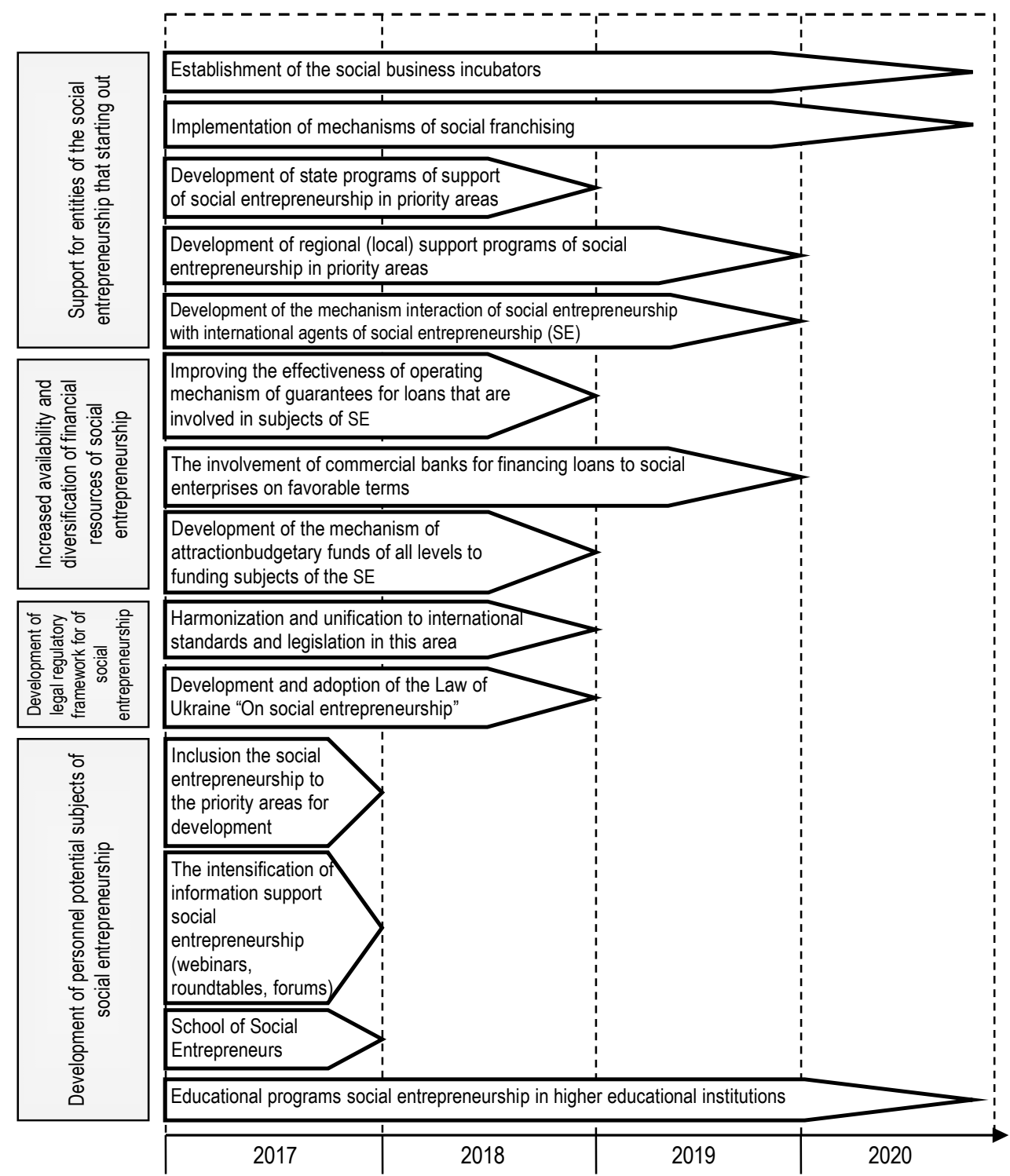

Figure 5 - Road mapping of the development social entrepreneurship in Ukraine (developed by the authors)

Prospects for further research should include the formation of the optimal domestic model of social entrepreneurship, the identification of drivers and ways to promote its development. 
В.В. Смачило, В.Ю. Халіна, Є.В. Кильницька. Розвиток соціального підприємництва в Україні як інноваційної форми бізнесу

1. Richardson M. Social Enterprise: Lessons learned from the UK / M. Richardson // Доповідь на II Всеукраїнському форумі соціальних підприємців. - Київ, 16.11.2016.

2. Наумова М. Сутність соціального підприємництва та його роль у соціально-економічному розвитку суспільства / М. Наумова // Україна: аспекти праці. - 2014. - № 4. - С. 34-39.

3. Dees J.G. The meaning of "social entrepreneurship" [Електронний ресурс] / J.G. Dees. - Режим доступу: http://www.caseatduke.org/documents/dees_sedef.pdf.

4. Дис Г.Дж. Лаборатория знаний [Електронний ресурс] / Г.Дж. Дис // Финансы и развитие, ежеквартальный журнал Международного валютного фонда. - 2012. - № 4. - Режим доступу: http://www.imf.org/external/russian/pubs/ft/fandd/2012/12/pdf/dees.pdf.

5. Peredo A.M. Social entrepreneurship: A critical review of the concept / A.M. Peredo, M. McLean // Journal of World Business. - 2006. - № 41(1). - P. 56-65.

6. Spear R. Social entrepreneurship: A different model / R. Spears // International Journal of Social Economics. - 2006. №33. - P. 399-410.

7. Офіційний сайт WNISEF [Електронний ресурс]. - Режим доступу: http://www.wnisef.org/ual.

8. Спреклі Ф. Посібник з Планування Соціального Підприємництва [Електронний ресурс] / Ф. Спреклі. - Британська Рада. - 2011. - 68 с. - Режим доступу: www.britishcouncil.org.

9. Nyssens M. (ed.) Social Enterprise. At the Crossroads of Market. - Public Policies and Civil Society, (Routledge, 2006), p. 4-5.

10. Roger L.M. Social Entrepreneurship: The Case for Definition [Електронний ресурс] / L.M. Roger, S. Osberg // Stanford social innovation review. - 2007. - Режим доступу: http://skollfoundation.wpengine.netdna-cdn.com/wpcontent/uploads/2010/09/2007SP_feature_martinosberg.pdf.

11. Кот Л. До питання про природу і сутність соціального підприємництва / Л. Кот // Bulletin of Taras Shevchenko National University of Kyiv. Economics. - 2014. - № 12(165). - C. 25-30.

12. What is a Social Entrepreneur? [Електронний ресурс]. - Режим доступу: http://www.schwabfound.org/content/whatsocial-entrepreneur.

13. Mair J. Social entrepreneurship research: A source of explanation, prediction, and delight [Електронний ресурс] / J. Mair, I. Marti // Journal of World Business. - 2006. - №41(1). - P. 36-44. - Режим доступу: https://c.ymcdn.com/sites/www.usasbe.org/resource/resmgr/social_entrepre neurship/mair_and_marti.pdf.

14. Офіційний сайт міжнародної організації соціальних підприємців [Електронний ресурс]. - Режим доступу: https://www.ashoka.org/.

15. Господарський Кодекс України [Електронний ресурс]. - Режим доступу: www.rada.gov.ua.

16. Глобальний договір $\mathrm{OOH}$ [Електронний ресурс]. - Режим доступу: http://www.mlsp.gov.ua/labour/control/uk/publish/article\%3Bjsessionid=07E30561B5BF4DDE28B50412BE5BA03D?art_id=88867 \&cat_id $=34940$.

17. Цілі Сталого розвитку в Україні [Електронний ресурс]. - Режим доступу. http://www.un.org.ua/ua/tsili-rozvytkutysiacholittialtsili-staloho-rozvytku.

18. Сіренко Н.М. Соціальне підприємництво в Україні: основні аспекти / Н.М. Сіренко, Т.І. Лункіна // Сталий розвиток економіки. - 2016. - №1. - С. 5-10.

19. Березяк I.I. Зарубіжний досвід та вітчизняні реалії становлення соціального підприємництва / І.І. Березяк // Наукові записки Національного університету «Острозька академія». Серія «Економіка» : збірник наукових праць. - 2014. Вип. 25. - С. $31-36$

20. Соціальне підприємництво. Досвід Норвегії [Електронний ресурс]. - Режим доступу: http://lcci.com.ua/socialnepidpryyemnyctvo-dosvid-norvegij/.

21. Указ Президента України «Про Стратегію сталого розвитку "Україна - 2020"». [Електронний ресурс]. - Режим доступу. - http://zakon1.rada.gov.ua/laws/show/5/2015.

22. Постанова КМУ №385 від 6.08.2014p. «Про затвердження Державної стратегії регіонального розвитку на період до 2020 року». [Електронний ресурс]. - Режим доступу. -http://zakon2.rada.gov.ua/laws/show/385-2014-\%D0\%BF.

23. Соціальне підприємництво - неоцінена необхідність [Електронний ресурс]. - Режим доступу: http://gazeta.dt.ua/economics_of_regions/socialne-pidpriyemnictvo-neocinena-neobhidnist-_.html.

24. Сотула О.В. Соціальне підприємництво як інноваційна модель розвитку економіки [Електронний ресурс] О.В. Сотула // Ефективн економіка. - 2013. - № 4. - Режим доступу: http://www.economy.nayka.com.ua/?op=1\&z=1988.

25. Гусак Н. Кращий досвід та сучасні тренди розвитку соціального підприємництва: Україна (результати дослідження) / Н. Гусак // Доповідь на II Всеукраїнському форумі соціальних підприємців. - Київ, 16.11.2016.

26. Бутенко А.І. Інституційні механізми підвищення ефективності використання потенціалу малого підприємництва / А.І. Бутенко, Н.Л. Шлафмман // Економічні інновації. - 2014. - № 57. - С. 43-50.

27. Янчук М.Б. Дорожні карти як метод державного регулювання інтегративного розвитку авіабудівних підприємств України [Електронний ресурс] / М.Б. Янчук // Теоретичні і практичні аспекти економіки та інтелектуальної власності. 2013. - Вип. 2(1). - С. 203-208. - Режим доступу до журн.: http://nbuv.gov.ua/UJRN/Tpaeiv_2013_2(1)_34.

28. Юнус М. Создавая мир без бедности Социальный бизнес и будущее капитализма / М. Юнус, А. Жоли . - Москва 
Альпина Паблишер, 2009. - 307с.

29. Офіційний сайт Фонду соціального підприємництва Шваба [Електронний ресурс]. - Режим доступу: http://www.schwabfound.org.

30. Офіційний сайт Фонда Сколла [Електронний ресурс]. - Режим доступу: http://www.skollfoundation.org.

1. Richardson, M. (16.11.2016). Social Enterprise: Lessons learned from the UK. II Vseukrainskiy forum sotsialnykh pidpryiemtsiv. Kyiv [in English].

2. Naumova, M. (2014). Sutnist sotsialnoho pidpryiemnytstva ta joho rol u sotsialno-ekonomichnomu rozvytku suspilstva [The essence of social entrepreneurship and its role in the socio-economic development of society]. Ukraina: aspekty pratsi Ukraine: aspects of work, 4, 34-39 [in Ukrainian].

3. Dees, J.G. (n.d.). The meaning of "social entrepreneurship". caseatduke.org. Retrieved from http://www.caseatduke.org/documents/dees_sedef.pdf [in English].

4. Дис, Г.Дж. (2012). Лаборатория знаний [Knowledge lab]. Finansyi i razvitie - Finance and development, 4. Retrieved from http://www.imf.org/external/russian/pubs/ft/fandd/2012/12/pdf/dees.pdf [in Russian].

5. Peredo, A.M., \& McLean, M. (2006). Social entrepreneurship: A critical review of the concept. Journal of World Business 41(1), 56-65 [in English].

6. Spear, R. (2006). Social entrepreneurship: A different model. International Journal of Social Economics, 33, 399-410 [in English].

7. Ofitsijnyj sajt WNISEF [Official WNISEF Website]. wnisef.org. Retrieved from: http://www.wnisef.org/ua/ [in Ukrainian].

8. Sprekli, F. (2011). Posibnyk z Planuvannia Sotsial'noho Pidpryiemnytstva [Guide to Planning for Social Entrepreneurship]. Brytanska Rada. Retrieved from: http:// www.britishcouncil.org [in Ukrainian].

9. Nyssens, M. (2006). Social Enterprise. At the Crossroads of Market. (pp. 4-5). Routledge, Public Policies and Civil Society [in English].

10. Roger, M.L., \& Osberg, S. (2007). Social Entrepreneurship: The Case for Definition. skollfoundation.wpengine.netdnacdn.com. Retrieved from http://skollfoundation.wpengine.netdna-cdn.com/wp-content/uploads/2010/09/2007SP_feature_ martinosberg.pdf [in English].

11. Kot, L. (2014). Do pytannia pro pryrodu i sutnist' sotsial'noho pidpryiemnytstva [The question of the nature and essence of social entrepreneurship]. Visnyk Kyivskoho natsionalnoho universytetu imeni Tarasa Shevchenka. Ekonomika - Bulletin of Taras Shevchenko National University of Kyiv. Economics, 12(165), 25-30 [in Ukrainian]

12. What is a Social Entrepreneur? (n.d.). schwabfound.org. Retrieved from: http://www.schwabfound.org/content/whatsocial-entrepreneur [in English].

13. Mair, J., \& Marti, I. (2006). Social entrepreneurship research: A source of explanation, prediction, and delight. Journal of World Business, 41(1). Retrieved from https://c.ymcdn.com/sites/www.usasbe.org/resource/resmgr/social_entrepre neurship/mair_and_marti.pdf [in English].

14. Ofitsijnyj sajt mizhnarodnoi orhanizatsii sotsial'nykh pidpryiemtsiv [Official site of the international organization of social entrepreneurs]. www.ashoka.org. Retrieved from https://www.ashoka.org/ [in English].

15. Hospodarskyi kodeks Ukrainy [Commercial Code Ukraine]. (2003, January16). Vidomosti Verkhovnoi Rady Ukrainy Bulletin of Verkhovna Rada of Ukraine. Kyiv: Parlam. vyd-vo [in Ukrainian].

16. Hlobalnyj dohovir OON [UN Global Compact]. (n.d.). m/sp.gov.ua. Retrieved from:http://www.mlsp.gov.ua/labour/control/uk/publish/article\%3Bjsessionid=07E30561B5BF4DDE28B50412BE5BA03D?art_id=88 $867 \&$ cat_id=34940 [in Ukrainian].

17. Tsili Staloho rozvytku v Ukraini [The goals of Sustainable Development in Ukraine]. (n.d.). un.org.ua. Retrieved from: http://www.un.org.ua/ua/tsili-rozvytku-tysiacholittia/tsili-staloho-rozvytku [in Ukrainian].

18. Sirenko, N.M., \& Lunkina, T.I. (2016). Sotsial'ne pidpryiemnytstvo v Ukraini: osnovni aspekty [Social entrepreneurship in Ukraine: the main aspects]. Stalyj rozvytok ekonomiky - Sustainable development of the economy, 1, 5-10 [in Ukrainian].

19. Bereziak, I.I. (2014). Zarubizhnyj dosvid ta vitchyzniani realii stanovlennia sotsial'noho pidpryiemnytstva [Foreign experience and domestic realities of social enterprise]. Naukovi zapysky Natsionalnoho universytetu "Ostrozka akademiia". Seriia "Ekonomika" - Scientific notes of the National University of Ostroh Academy. Series "Economics", 25, 31-36 [in Ukrainian].

20. Sotsialne pidpryiemnytstvo. Dosvid Norvehii [Social entrepreneurship. Norway's experience]. (n.d.). Icci.com.ua. Retrieved from http://lcci.com.ua/socialne-pidpryyemnyctvo-dosvid-norvegiji/ [in Ukrainian].

21. Ukaz Prezydenta Ukrainy "Pro Stratehiiu staloho rozvytku "Ukraina - 2020". [Decree of the President of Ukraine "On the Strategy of Sustainable Development" Ukraine - 2020"]. (n.d.). rada.gov.ua. Retrieved from http://zakon1.rada.gov.ua/laws/ show/5/2015 [in Ukrainian]

22. Postanova KMU №385 "Pro zatverdzhennia Derzhavnoi stratehii rehionalnoho rozvytku na period do 2020 roku" [CMU Resolution No.385 "On approval of the State Strategy for Regional Development for the period up to 2020"]. (n.d.). rada.gov.ua Retrieved from http://zakon2.rada.gov.ua/laws/show/385-2014-\%D0\%BF [in Ukrainian].

23. Sotsialne pidpryiemnytstvo - neotsinena neobkhidnist' [Social entrepreneurship is an invaluable need]. (n.d.). gazeta.dt.ua. Retrieved from http://gazeta.dt.ua/economics_of_regions/socialne-pidpriyemnictvo-neocinena-neobhidnist-_.htm [in Ukrainian]. 
В.В. Смачило, В.Ю. Халіна, Є.В. Кильницька. Розвиток соціального підприємництва в Україні як інноваційної форми бізнесу

24. Sotula, O.V. (2013). Sotsialne pidpryiemnytstvo iak innovatsijna model rozvytku ekonomiky [Social entrepreneurship as an innovative model of economic development]. Efektyvna ekonomika - Effective economy, 4. Retrieved from http://www.economy.nayka.com.ua/?op=1\&z=1988 [in Ukrainian]

25. Husak, N. (16.11.2016). Kraschyj dosvid ta suchasni trendy rozvytku sotsialnoho pidpryiemnytstva: Ukraina (rezultaty doslidzhennia) [Best Experience and Contemporary Trends in the Development of Social Entrepreneurship: Ukraine (Research Results)]. II Vseukrainskiy forum sotsialnykh pidpryiemtsiv. Kyiv [in Ukrainian].

26. Butenko, A.I., \& Shlafman, N.L. (2014). Instytutsijni mekhanizmy pidvyschennia efektyvnosti vykorystannia potentsialu maloho pidpryiemnytstva [Institutional mechanisms for increasing the efficiency of using the potential of small business] Ekonomichni innovatsii - Economic innovations, 57, 43-50 [in Ukrainian].

27. Yanchuk, M.B. (2013). Dorozhni karty iak metod derzhavnoho rehuliuvannia intehratyvnoho rozvytku aviabudivnykh pidpryiemstv Ukrainy [Road maps as a method of state regulation of the integrative development of aviation building enterprises of Ukraine]. Teoretychni i praktychni aspekty ekonomiky ta intelektual'noi vlasnosti - Theoretical and practical aspects of economics and intellectual property, 2(1). Retrieved from http://nbuv.gov.ua/UJRN/Tpaeiv_2013_2(1)_34 [in Ukrainian].

28. Yunus, M., \& Zholy A. (2009). Sozdavaia myr bez bednosty Sotsyalnbil byznes y budushchee kapytalyzma [Creating a World without Poverty: Social Business and the Future of Capitalism]. Moscow: Alpyna Pablysher [in Russian].

29. Ofitsijnyj sajt Fondu sotsialnoho pidpryiemnytstva Shvaba [Official site of the Schwab Foundation for Social Entrepreneurship]. www.schwabfound.org. Retrieved from: http://www.schwabfound.org [in English].

30. Ofitsijnyj sajt Fonda Skolla [Official site of the Skoll Foundation]. www.skollfoundation.org. Retrieved from: http://www.skollfoundation.org [in English].

B.B. Смачило, канд. екон. наук, доцент, професор кафедри економіки, Харківський національний університет будівництва та архітектури (м. Харків, Україна);

В.Ю. Халіна, канд. екон. наук, доцент кафедри економіки, Харківський національний університет будівництва та архітектури (м. Харків, Україна);

Є.B. Кильницька, канд екон. наук, доцент кафедри економіки, Харківський національний університет будівництва та архітектури (м. Харків, Україна)

Розвиток соціального підприємництва в Україні як інноваційної форми бізнесу

у даній статті проведено теоретичне дослідження основних аспектів соиіального підприємництва, а саме: узагальнено погляди науковців на його ознаки, розмежовано поняття "соціальне підприємство", "соціально відповідальне підприємство", "благодійні організації", вивчено досвід соціального підприємництва в країнах Європи та специфріку його законодавчого регулювання, визначено основні моделі функиіонування соціальних підприємств відповідно до світових практик ведення цього специфічного виду бізнесу, його організаційно-правові форми та сффери діяльності. Виявлено основні проблеми становлення соціального підприємництва в Україні, а також розроблено дорожню карту його подальшого розвитку.

Ключові слова: соціальне підприємництво, інноваційна форма бізнесу, ознаки соціального підприємництва, моделі соціального підприємництва, дорожня карта.

B.B. Смачило, канд. экон. наук, доцент, профессор кафедры экономики, Харьковский национальный университет строительства и архитектуры (г. Харьков, Украина);

B.Ю. Халина, канд. экон. наук, доцент кафедры экономики, Харьковский национальный университет строительства и архитектуры (г. Харьков, Украина)

E.B. Кильницкая, канд. экон. наук, доцент кафедры экономики, Харьковский национальный университет строительства и архитектуры (г. Харьков, Украина)

Развитие социальной предпринимательства в Украине как инновационной формы бизнеса

В данной статье проведено теоретическое исследование основных аспектов социального предпринимательства, а именно: обобщены взгляды ученых на его признаки, разграничены понятия "социальное предприятие", "социально ответственное предприятие", "благотворительные организации", изучен опыт социального предпринимательства в странах Европы и специфиика его законодательного регулирования, определень основные модели функиионирования соииальных предприятий в соответствии с мировыми практиками ведения этого специфического вида бизнеса, его организационно-правовые формы и сферы деятельности. Выявлены основные проблемы становления оциального предпринимательства в Украине, а также разработана дорожная карта его дальнейшего развития.

Ключевые слова: социальное предпринимательство, инновационная форма бизнеса, признаки социльного предпринимтельства, модели социального предпринимательства, дорожная карта.

Отримано 21.05.2017 p. 